\title{
Meet the New Hormones and Cancer Editorial Team: Nancy L. Weigel, Editor-in-Chief
}

Published online: 16 January 2015

(C) Springer Science+Business Media New York 2015

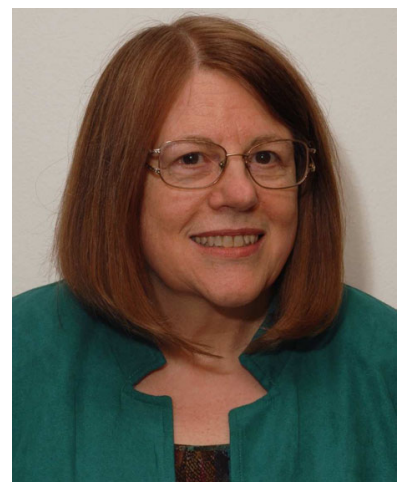

Nancy L. Weigel, $\mathrm{PhD}$, is a professor in the Department of Molecular and Cellular Biology and the Scott Department of Urology at Baylor College of Medicine in Houston, TX. Dr. Weigel obtained her bachelor's degree from Cornell University in Ithaca, NY and earned her Ph.D. in Biochemistry at Johns Hopkins in Baltimore, MD. Dr. Weigel's PhD thesis on the structure of Salmonella Typhimurium HPR was written under the mentorship of Dr. Saul Roseman. Further post-doctoral studies at Baylor College of Medicine with Dr. Bert O'Malley focused on steroid receptors.

She is chairwoman of the Endocrine Society's Laureate Awards Committee and has served on the Society's Council as well as the Publications Core Committee. Dr. Weigel has previously served as Associate Editor for the Society's journal, Molecular Endocrinology, and is or has been an editorial board member for Hormones and Cancer, Endocrinology, Steroids, Nuclear Receptor Signaling, and the Journal of Biological Chemistry. Dr. Weigel has been honored with the Society's Roy O. Greep Award for Outstanding Research and the Society of Women in Urology/Society for Basic Urology Research Award for Excellence in Urologic Research.

In her own research, Dr. Weigel has investigated the role of cell signaling in progesterone receptor action, coactivators and androgen receptors in prostate cancer, as well as the role of vitamin D receptors in prostate cancer target genes. In the last 3 years, Dr. Weigel has completed studies including analysis of the role of androgen receptor splice variants in castration resistant prostate cancer, the regulation of progesterone receptors by phosphorylation, and TMPRSS2-ERG gene fusions and vitamin $\mathrm{D}$ action in prostate cancer, among others.

Dr. Weigel brings a wide breadth of knowledge and editorial experience to Hormones and Cancer that will facilitate continued excellence and future growth. At the end of her 3 year term, Dr. Weigel's goal for Hormones and Cancer is to have developed it into a journal that authors think of as one of the first possibilities for submission in this area, particularly when their studies contain components of basic science and more translational research including analyses of clinical data. 